\title{
Stigmatisation of Indigenous Knowledge: The Case of Night-running in Western Kenya
}

\author{
Tom Kwanya \\ Department of Information and Knowledge Management, \\ The Technical University of Kenya, Nairobi, Kenya; \\ Research fellow in the Department of Information Science, \\ University of South Africa, Pretoria, South Africa \\ tkwanya@tukenya.ac.ke
}

\begin{abstract}
Night-runners are perceived as faceless, evil people who run naked in the darkness, thereby wreaking havoc in otherwise peaceful rural villages. This paper investigates the origins of night-running, the mysteries associated with it, the benefits and harms of night-running, and the impact of indigenous knowledge (IK) stigmatisation on this practice. Indigenous knowledge is the body of unique beliefs, attitudes, skills, and practices possessed by communities in a specific geographic setting. In spite of its potential value, scholars point out that indigenous knowledge has been neglected, vindicated, stigmatised, legalised, and suppressed among the majority of the world's communities due to ignorance and arrogance. Night-running is one of the indigenous practices in Western Kenya that has been stigmatised. Given this, little is actually known about night-running. This study was designed as an ethnographic research through which the views of the residents of Homa Bay County on night-running were investigated, collated, and interpreted as a means of demystifying this indigenous practice. The findings of the study indicate that night-running is intrinsically a harmless practice. However, evil persons such as witches sometimes masquerade as night-runners and can hurt or kill people.
\end{abstract}

\section{Keywords}

indigenous knowledge - stigma - night-running - night-runners - Kenya 


\section{Introduction}

Scholars have provided varied definitions of what constitutes indigenous knowledge (IK). Johnson (1992) defines it as a body of knowledge developed by a group of people through generations of living in close contact with nature. Smith (1999) suggests that IK is a term that captures the experiences, concerns, struggles, and survival of some of the world's most isolated people. Ocholla (2007) perceives IK as a complex set of knowledge and technologies existing and developed around specific conditions of populations and communities indigenous to a particular geographic area. Onyancha and Ocholla (2004) define IK as a dynamic archive of the sum total of knowledge, skills, and attitudes belonging to a community over generations and expressed in the form of action, objects, and language. On their part, Warren (1991) and Flavier et al. (1995) demarcate IK as the local knowledge or knowledge that is unique to a given culture or society. In this paper IK is perceived as the set of unique skills, knowhow, technologies, and practices that a group of people living in a specific geocultural setting hold and pass on. In this context, night-running is considered a form of indigenous sport encompassing athletics, gymnastics, and aerobics performed at night for recreational, spiritual, and health purposes. This work thus perceives night-running to be a form of indigenous knowledge that has been passed on intangibly through generations of the communities and families that practise it.

Characteristically, IK is local because it is ingrained in a specific community, established within the boundaries of broader cultural traditions and developed by a specific community, intangible and consequently not easily codified, conveyed orally, experimental rather than theoretical, and learned through repetition (World Bank 1997). IK is creative and experimental; it is constantly incorporating outside influence and internal innovations to meet emerging local needs (Langill 1999). Johnson (1992) adds that IK evolves in the local environment so that it is specifically adapted to the needs and conditions of the local people. Thus it is not old-fashioned, backward, or static. Semali and Kincheloe (1999) hold the view that indigenous knowledge reflects the dynamic way in which the residents of an area have come to understand themselves in relation to their environment and how they organise that folk knowledge of flora and fauna, cultural beliefs, and history to improve their lives. Flavier et al. (1995) concur that IK systems are dynamic and are continually influenced by internal creativity and experimentation as well as by contact with external systems. It is the opinion of this author that whereas IK inevitably evolves as a consequence of external and internal factors, it philosophically remains unchanged and unique to specific community contexts to the extent 
that it is identifiable, codified, packaged, and disseminated through generations using verbal and nonverbal communication.

IK contrasts with the scientific knowledge system generated by universities, research institutions, and private firms. Fleer (1999) explains the distinction between IK and scientific knowledge through the concept of worldviews. She points out that while indigenous knowledge is founded on a traditional worldview and produced for specific purposes to maintain particular societies, scientific knowledge is founded on the "civilised" worldview and produced for its own sake. She argues that while scientific knowledge seeks power over nature and people, indigenous knowledge seeks to coexist with the same. She describes scientific knowledge as being materialistic, reductionist, rational, decontextualised, individual, and competitive while in contrast she extols indigenous knowledge as being spiritual, holistic, intuitive, contextualised, communal, and cooperative. IK is the basis for local-level decision making in agriculture, health care, food preparation, education, natural resource management, and a host of other activities in rural communities (Warren 1991). Sahai (2003) explains that indigenous knowledge is the foundation of all knowledge since modern scientific knowledge emerged from it. This view is premised on the understanding that indigenous knowledge existed before scientific knowledge was developed. Indeed, scientific knowledge as we know it today emerged as a means of validating, extending, leveraging, or perpetuating existing indigenous knowledge.

\section{$2 \quad$ Rationale of Study}

In spite of the understanding that it is the foundation of modern scientific knowledge, Agrawal (1995) argues that some parties perceive IK to be inefficient, inferior, and antidevelopment. Onyancha and Ocholla (2004) argue that IK has been neglected, vindicated, stigmatised, illegalised, and suppressed among the majority of the world's communities. However, Semali and Kincheloe (2002) assert that IK is gaining prominence in the search for solutions to challenges relating to socioeconomic development and the prosperity of societies, not just in the indigenous but also in the global community. In fact, Agrawal (1995) reports that IK has become a new area of attraction in development, as demonstrated by the interest that the field has attracted among researchers, donors, writers, and scholars. He further explains that although IK was earlier viewed as inferior, inefficient, and an obstacle to development, today's thinking has recognised the value it holds for sustainable development. The increased focus on IK represents a shift from the preoccupation 
with the scientific knowledge that has generally failed to sustainably improve the lives of the majority of the poor over the last decades. It is important to note, however, that the increasing attention indigenous knowledge is receiving from academic and development institutions has not yet led to a unanimous perception or appreciation of it. This is in spite of the emergence of the school of thought that posits that a country's ability to build and mobilise knowledge capital is as essential for sustainable development as the availability of physical and financial capital (World Bank 1997). The basic component of any country's original knowledge system is its indigenous knowledge that encompasses the skills, experiences, and insights of its indigenous people collectively applied to maintain or improve their unique livelihoods. Thus what a country knows is essentially the accumulation of the discrete IK held by its indigenous communities. Nation-states need to creatively amalgamate these pieces of IK to build strategic reservoirs of national knowledge capital that are unique to their contexts and needs.

Night-running is one of the deeply stigmatised indigenous practices in Homa Bay County, Western Kenya. In the face of this stigma, little is actually known about night-running and its place, if at all, in the socioeconomic ecosystem in society. The specific objectives of this study are to investigate the origins of the practice, explore the mysteries associated with night-running, examine the benefits or harms of night-running in Western Kenya, and assess the impact of IK stigmatisation on this practice.

Methodology

This study was designed as an ethnographic research work. Blomberg et al. (1993) explain that the hallmark of an ethnographic approach is its emphasis on understanding the research issues from the perspectives of the subjects, holism, and natural settings. Therefore ethnographic studies are best conducted through fieldwork in which the researcher is immersed in the activities of the people being studied through observation, informal interviews, and participation in ongoing community events. The researcher thereafter interprets and gives meaning to the observed behaviour and activities.

Through this approach, the views of the residents of Homa Bay County in Western Kenya on night-running were obtained, then collated and interpreted them as a means of demystifying this indigenous practice. Data was collected from April to May 2017 through in-depth interviews conducted in Dholuo (the local vernacular). The population of the study consisted of ordinary citizens, village elders, people who have encountered night-runners and 
Category of respondents Frequency of respondents

Ordinary citizens $\quad .20$

Village elders $\quad .6$

Victims of night-running $\quad .10$

Self-confessed night-runner $\quad .1$

Total

.37

a self-confessed night-runner. Ordinary citizens provided general opinions about night-running. Village elders serve as the "libraries" of the community, and are authorities on communal indigenous knowledge. The information that the elders provided was used to validate that provided by the ordinary citizens. Victims of night-runners and the self-confessed night-runner provided firsthand information about the practice as well as its status and consequences. The respondents were identified through snowballing. A total of 37 respondents were interviewed. Specific details regarding the respondents are presented in Table 1.

Although all ten homes of the people who claimed they had been victims of night-running were visited, night-runners actually appeared on only three occasions.

Additional data on night-running as well as its stigmatisation was collected through a review of literature on night-running. The reviewed literature included books and journal articles as well as mass and social media articles. The author focused on the details of night-running reported or discussed in the various literature as well as the attitudes of their authors toward night-running. This information was used to assess the levels and types of stigmatisation of the practice.

\section{$4 \quad$ Night-running in Literature: A Bibliometrics Analysis}

As a means of obtaining a glimpse into the volume of literature produced on night-running in Kenya, a bibliometrics analysis of the subject was conducted. Using Harzing's "Publish or Perish" software, the author obtained 54 information materials on night-running in Kenya from Google Scholar. These materials were published between 1901 and 2017. These publications comprised books, book reviews, citations, journal articles, theses or dissertations, web documents, and an e-mail message. In general, these publications include writings 
of colonial officials that portrayed night-running as a nuisance that the administrators were required to deal with firmly; documents compiled by missionaries that condemned the practice as a heathen shackle from which converts should break loose; accounts of anthropologists as well as religion and philosophy scholars seeking to document and debate traditional Luo customs; fictional and theatrical presentations of nocturnal activities in rural Africa; and academic theses discussing cultural rites, music, and myths.

Night-running or night-runners were mere mentions in most of the retrieved literature. It is also noteworthy that there was no article dedicated wholly to night-running or night-runners. This is an indication of low literature productivity perhaps emanating from a lack of interest in the subject. It may also be attributed to the mystery and stigma surrounding the phenomenon or the fear of being associated with it. Most of the materials were published after 2000; only eight were published prior to this date. This indicates an increasing interest on the subject or the reduction of fear regarding it. Already there is heightened mass media interest on the subject, which has resulted in several articles being published in the local and international media, including the ввс. ${ }^{1}$ The current growing interest may have arisen from the call by one Jack Songo, the self-proclaimed "president" of night-runners in Kenya, for the recognition of the practice as a sport and the registration of an association for night-runners (Orwa 2013). This activism seems to have borne some fruit given news reports ${ }^{2}$ that in 2019 the Homa Bay County Commissioner advised nightrunners in the county to remain indoors at night so as to be counted during the 2019 national census. This author predicts increased interest and research productivity on the subject in the future.

The retrieved literature covered a wide array of issues, including cultural practices and taboos; music and dance; language, literature and poetry; contemporary beliefs; and ethnicity and ethnic stereotyping. They also addressed gender roles and discrimination; traditional marriage and family; nature of human beings; death, spirits, and the afterworld; God and religion; traditional medicine, witchcraft, and magic; as well as crime, chaos, and disorder in society. The diversity of these themes associated with night-running points to an inadequate understanding of the phenomenon. It is also an indication of multidisciplinary attempts to unravel the practice, albeit with marginal success.

What is Night-running?

One of the strategies of unravelling night-running is by considering the perceptions of who a night-runner is. According to Amuka (2000), night-runners 
are as mysterious as riddles because their actions are undertaken in the secrecy of the night. Nonetheless, Picasso (2016) explains that night-runners are persons who run naked at night and perform acts to scare or irritate other people. Oduor (2012) argues that a night-runner is a person who runs around peoples' homesteads in the dead of night, causing paralysing fear. According to Ocholla (1976), night-runners are distinct from witches in that they are harmless and do not cause deaths. Although persons who encounter night-runners report that they feel nervous, fearful, and mesmerised in their presence, night-runners are simply nuisances who disturb people's sleep. According to Nyasani (1997), this running in the night could be for amusement and does not indicate that the night-runners have bad intentions. For this reason the victims of night-runners generally let them be. However, when it is extreme, they lay traps to catch them. One common trap is leaving the door open or covering it with a sheet. The unsuspecting night-runners would attempt to kick the door but would instead be thrown into the house. They would then be caught and punished, for example, by extradition or fines. However, there is a school of thought that views night-runners as antisocial outcasts who are categorised together with deviants, wizards, witches, thieves, and suicidal people. The respondents to this study disagreed with this view, explaining that harmful "night-runners" are actually witches. Such "night-runners" are also reported to tame wild animals such as hippos, leopards, snakes, hyenas, and crocodiles, which they ride at night. These "night-runners" not only scare but can also harm their victims, for instance striking them dumb or even killing them.

In the context of this paper, night-running is viewed as an intrinsically harmless practice of some individuals to perform strange, mischievous, and frightening acts in their neighbourhoods at night. Its basic goal is not exercise but to frighten and poke fun at the victims. Night-running does not ordinarily lead to bodily harm or death since genuine night-runners are harmless. It is the harmful people, such as witches, who masquerade as night-runners who cause the confusion between night-running and witchcraft, thereby associating the practice with intentional harm. Unfortunately it is not easy to distinguish between genuine night-runners and witches since they perform their acts in the secrecy of darkness while naked or adorned with strange accessories. This view concurs with Ocholla (1976), Nyasani (1997), and Masolo (2010).

According to Oduor (2012), night-running originates from a kind of force or power that compels the individuals to act in weird ways. This view is supported by the respondents' assertions that night-runners are ordinary people 
during the day but are transformed into strange beings who exhibit weird habits at night. As one respondent observed, 'Ok ding'e jojuogi g'odiechieng'. Gichal mana gi ji mamoko. Otieno to gipogore mokalo' (You cannot pick out the night-runners during the day since they behave just like everyone else but they change at night) (Victim 7, Kendu Bay). The respondents argued that night-runners are helpless people under some mystic powers that possess them at night: 'Juok idho jojuogi kendo chunogi ni nyaka giringi eka giyud kwe' (The spirit of night-running possesses the people and forces them to run before they can find relief) (Elder 3, Homa Bay town). The respondents asserted that these powers are evil because they drive night-runners to perform acts that frighten peace-loving people. Given that night-runners derive pleasure in tormenting other people, the respondents concluded that their powers are demonic.

Most night-runners are individuals who inherited the behaviour from their ancestors and passed it on to their descendants: 'Juok pitipiti inyuologo ji. Anyuola mar jojuogi ong'ere' (Night-running is inherited at birth. Families of night-runners are known) (Ordinary Citizen 11, Lambwe Valley). Another respondent claimed, 'Nyathi jajuok ok nyal weyo ido. Koweyo to ok onyuol kendo onyalo kata tho' (Children of night-runners cannot stop the practice otherwise they may not bear children or may even die) (Elder 6, Rangwe). It was the respondents' opinion that night-runners have no choice about continuing the practice. However, the respondents also explained that in some cases nightrunning can be learned through association and socialisation. For instance, 'Mon monyuom e miere jojuogi ichuno nyaka gipuonjre juok eka gidagi' (Women who marry into the homes of night-runners are forced to learn the practice to remain in the marriage' (Ordinary Citizen 17, Mbita). Similarly, foreigners who lived in night-running communities could also learn this behavior. In fact, there are reports in the literature that even Caucasians can learn the habit through close interactions with night-runners. Ochieng (2002), Atieno-Odhiambo (2002), and Onyango-Abuje (1975) narrate incidents in which foreigners reportedly learned night-running while living in Western Kenya. One commonly cited case is that of a European man teaching at Mbita High School in Homa County who had learned night-running and practised it covertly, believing it was a virtuous habit. When he would be caught running naked at night he would openly respond, 'Aido', meaning 'I am night-running' in the local Dholuo language.

One view in the literature claimed that night-runners may be drug addicts. Writing about night-runners in Rusinga Island in Homa Bay County, Weckenbrock and Oldesloe (2005:54) argue that these are 'persons, who, after the consumption of drugs, stay outside naked during the night and try to harm other people'. However, the respondents in this study did not support this view, 
arguing that most night-runners are actually teetotallers because it is not possible to run or jump while intoxicated. Although they acknowledged that 'jojuogi moko madho njaga mondo giyud teko marng'wech' (some night-runners use bhang to energise for the practice) (Elder 3, Homa Bay town), they insisted that the influence of drugs was not the real reason for night-running.

Victims of night-runners believe they are possessed because of their weird behaviour, but this view can be refuted because they are alert and exercise intelligent judgment, which would not be possible if they were not in their right minds.

Opinion is divided on whether the 'spirit' of night-running can be exorcised. A follow-up interview with the respondents revealed that all the ordinary citizens and the self-confessed night-runner held the view that night-running is a powerful compulsion that never leaves the individual. According to them, night-runners could not stop the habit even if they wanted to, as one respondent summarised: 'Juok ng'ato ok nyal weyo nikech oringo e remo' (Night-runners cannot stop the habit because it runs in their blood) (Victim 8, Mbita).

The above assertion is interpreted to imply the compulsive power of nightrunning flows in their veins and is a critical facet of their very being. The elders, on the other hand, were of the view that night-runners could actually stop the habit after traditional healing (cleansing) or religious prayers. Asked whether they knew of any night-runners who had abandoned the habit, the elders answered affirmatively. However, they explained that very few people stopped night-running, adding that those who did were largely those who had acquired the habit through association, not through night-running kinsmen. This group of people included women who married into night-running families and foreigners socialised into the practice. There was also the view that night-running, like any other addiction, could be overcome under certain circumstances. For instance, night-runners who are injured, caught, or threatened grudgingly give up the habit so as to remain safe and accepted by the community. This author concludes that night-running is a learned habit that can be unlearned, albeit with immense difficulty.

Night-runners basically run around their neighbourhoods. They venture out after the village has gone to sleep and may stay out until dawn (King 1994). As they run, they are reported to perform the following strange acts:

- Running very fast, noisily, and naked

- Shaking peoples' houses, kicking their doors, and rattling windows 
- Swinging on tree trunks and branches

- Farting near other people's bedroom windows or defecating in front of their doors

- Throwing dirt into people's houses through gaps in the roof or walls

- Pelting iron-roofed houses with pebbles

- Performing weird dances and acrobatics

- Waylaying and scaring late travellers

- Making frightening sounds like wild animals

- Carrying mysterious fire as they run fast

Atieno-Odhiambo (2000) argues that night-runners do not like to be seen or identified, and are skilled in camouflage and hiding at night. If caught or identified, they appease those who catch them with gifts in order to keep the matter secret. The fact that they go to great lengths to cover their habit indicates that they are apologetic for their actions. One therefore wonders why they continue the practice. This is the reason why some respondents believe that nightrunners are under some strong supernatural power that compels them to do something they would otherwise not do if in their right senses.

Although night-runners are generally found in rural settings, some are found in the cities as well. ${ }^{3}$ Given the physical conditions and lighting in cities and towns, urban night-runners do not venture outside their compounds or houses. The respondents reported that urban night-runners kept two beds in their houses so that they could jump from one bed to the other. They also claimed: 'Jojuogi ok we juok kata gin ka pango kata ka wendo. Nyaka gitemie ng'wech matin eka chunygi ywe. Ka tek to gichikore e wi kombe' (The urge for night-running is so strong that the night-runners have to perform it even in urban centres or when visiting. If they cannot find space to run, they will jump up and down on furniture to relieve themselves) (Elder 2, Ndhiwa).

Night-runners select their victims carefully. They choose the most vulnerable, such as people who have just moved into the village, guests, or women living alone (Masolo 2010). Depending on the season or weather, night-runners can visit a victim's home more than once in one night. The intensity of each episode depends on the perception or reaction of the victim. The night-runners become more excited and vicious when the victim reacts or tries to catch them. They then gleefully start a game of hide and seek with the victim. The respondents observed, 'Jajuok mor ka ong'eyo ni iwinje' (Night-runners are gratified when they know that their victims are affected by their activities) (Victim 8, Mbita).

\subsection{Demystifying Night-running from a Practitioner's Perspective}

The author interviewed one self-confessed practising night-runner. However, when the author asked to observe him in action, he objected, raising doubts 
on whether he was actually a participant. It is also possible that he was an authentic night-runner but guarding the secrets of the practice. Even the selfproclaimed president of night-running, Jack Songo, recanted his own assertions that he was a night-runner when faced with a threat of exile from his neighbours. ${ }^{4}$ Nonetheless, this respondent made the following clarifications:

- Night-runners do not harm of kill people. However, they have powerful charms that enable them to perform supernatural acts. The charms are for their own use and are not applied to harm others.

- Some of the night-runners use tamed wild animals such as hippos and crocodiles as a way of demonstrating their supernatural power to control even the fiercest animals and difficult situations.

- Night-runners are brave and masters of the night. They spend up to six hours in their activities every night. They fear nothing because they are used to the night and nocturnal animals. They can chase even the fiercest animals such as leopards.

- Night-runners become possessed by powerful spirits, which makes them perform night-running activities to get relief. These powers are too strong to resist and thus they cannot stop once they have started the habit. This implies that taking up night-running is easier than stopping it.

- Night-runners are sometimes hurt or even killed by their would-be victims. Such cases are rare because night-runners are masterful at hiding. They are also skilled in psychology and can predict their victims' reactions beforehand.

- Night-runners run nude to be more mysterious and also to avoid being identified. Sometimes they wear weird accessories or tattered clothes to appear more frightening. Nudity also makes it easier to run and also to avoid sweating, since their scent could lead to identification.

- Night-runners do not just disappear, as many of their victims claim. They believe they escape to the underworld when cornered. Night-runners are simply masters of camouflage and move swiftly so that ordinary people cannot find them.

- People who are believed to have been killed by night-runners basically die of the health consequences of fright. Night-runners do not beat or hurt anyone. However, their theatrics can be so frightening that their victims could die of fear. In some cases the victims are speechless for days, leading people to believe that they were struck dumb by the night-runners' charms.

- The night-runners use mysterious sources of lights to help them see better in the darkness. The light can be from a torch or glowing firewood. Some night-runners are also acrobats who can perform strange acts such as swallowing or spitting fire. 
From this interview this author concludes that night-running is learned and perfected through practice. The claims of night-runners and their victims that they have charms and special powers are untrue. However, since they spend a great deal of time practising and perfecting the behaviour, their victims believe that they have special powers.

\section{8}

Possible Benefits of Night-running

All the respondents stated that night-running is a menace to their communities and should not be encouraged: 'Juok en kuong' ma ok owinjore gi ji ma obidhore' (Night-running is a curse that is not expected of decent people) (Victim 7, Kendu Bay). Asked to identify some benefits of night-running, they had little to say. However, they pointed out that night-runners boost neighbourhood security: 'Piny ma jojuogi nitie onge kwo' (There are no thieves in environments where there are night-runners) (Elder 4, Kendu Bay). The respondents also claimed that night-running or night-time jogging was healthy, stating that most night-runners were slim and healthy because of the many hours of jogging and other vigorous physical activities they engage in. The respondents also observed that night-running is a unique cultural activity in some communities that could be used as an attraction for indigenous tourism and serve as a source of income. They cited the case of a movement in Homa Bay County pushing for the recognition of night-running as a sport from which people could make a living.

It is evident from the views above that night-running is generally perceived as having no socioeconomic benefits. However, this author is of the view that there are potential benefits that society could accrue from the practice if it could be demystified. Similarly, if the practice is legitimised then it could be exercised ethically and thereby become more beneficial than it is currently perceived to be.

\section{Harmful Consequences of Night-running}

Although the respondents felt that ordinary night-running was harmless, they pointed out that it has some intended and unintended harmful consequences on the society's peace and tranquillity. Opinions in literature also reveal the view that night-running is harmful. For instance, Gumbo (2008) asserts that night-running is demonic and is driven by malevolence. Masolo (2010) states that night-runners exhibit animal behaviour and are uncaring 
to their village-mates, who are usually kinsmen. These views explain why people are discouraged from socialising with persons or families suspected to be night-runners. In fact, young men and women are forbidden from marrying into families of night-runners (Herbich and Dietler 2008). One respondent observed, 'Ji makendo ne igamo. Jagam nyaka ne tim nonro ma yud adieri kuom dala ma nyako kata wuowi aye. Nyar jajuok onge ng'at ma nyalo dakgo. Jojuogi nyuomore kendgi' (Families used go-betweens to identify suitors from families who are not night-runners. Youth from night-running families could only marry their counterparts in the practice) (Ordinary Citizen, Kendu Bay). Night-running was a valid reason for divorce in traditional society, and thus was a cause of stress and severance of societal ties.

One of the most cited harmful consequences of night-running is the view that some night-runners are also known to be witches. Such people hide under the guise of night-running but can kill their victims physically with a weapon, or through magic. This corroborates Weckenbrock and Oldesloe (2005), who hold the view that all night-runners are witches and assert that while night-runners mainly create fear in their victims, they can also kill persons through strangulation or using magic. The respondents explained that such cases were uncommon, and in fact could not cite any such cases in the recent past. Nonetheless, they believed that such harmful night-runners existed in the county.

The respondents also explained that night-runners can be destructive, especially when they use wild animals such as hippos that destroyed people's crops. Such animals, which the night-runners tame, can also create severe losses to the society by attacking or eating domestic animals and people: 'Jojuogi ma ringo gi rao kata nyang' kata ondiegi kelo kihondko kuom ji kendo ginyalo neko' (Night-runners who tame and ride wild animals like hippos, crocodiles, or hyenas are terrible because they can kill) (Elder 3, Home Bay town). One respondent stated that a night-runner used to untie and ride his dairy cow: 'Otieno ka otieno ne ayudo dhera e tok dala ka ool kendo dhoge wuok buoyo. Chieng' moro achiel ne ayudo mana ka otho e kul' (On several nights, I found my cow behind the homestead tired and foaming in the mouth. One day, I just found it dead) (Victim 7, Kendu Bay). In such cases night-running is not perceived as being harmless. The respondents explained that such night-runners could also be jealous neighbours driven by malice.

The presence of night-runners in particular communities sometimes led to migration. In fact, Dawo et al. (2015) report that the fear of night-runners was one of the reasons teachers in public secondary schools in Mbita and Suba subcounties in Homa Bay County sought to be transferred from their work stations. In these cases night-running affects peaceful existence and may jeopardise socioeconomic development activities. 
Due to the mystery and stigmatisation of the practice, many people do not want to be associated with night-runners. This leads to stereotypes, discrimination, and sometimes even death. According to Isaac (2014), old people suspected to be night-runners have been lynched in Kisii and Nyamira counties, which border Homa Bay County. Those who escape are forced to live in isolation away from their families and friends. Night-running is also causing divisions at the national level. Wendo (2016) explains that during the 2013 general elections in Kenya members of the Luo ethnic group were stereotyped by being branded as night-runners. This stereotyping was meant to isolate them from the rest of the country, and affected their acceptance and participation in nation building.

Although genuine night-running does not aim to cause any harm to society, night-runners can cause unintended harm to their victims. From the literature review and interviews, it is evident that the harm from night-running far outweighs its potential benefits. It is the opinion of this author that destigmatising the practice can reduce these harms. Since night-runners have been part of Homa Bay County from time immemorial, it cannot be ignored or wished away. Unless appropriate action is taken the practice will continue to harm society.

From the interviews and literature review, it is evident that night-running is stigmatised by being referred to as demonic and evil. The implication of this description is that the practice is harmful, backward, immoral, and antisocial and should therefore be shunned and discouraged by society. This negative branding can be attributed to the fact that the origin of night-running is mysterious. In fact, available explanations about the origins of night-running are biased speculations aimed at maintaining this negative branding. The fact that night-runners operate in the secrecy of darkness compounds the mystery surrounding the practice. Night-runners fear being identified because this can lead to grave consequences, including lynching, divorce, or alienation.

The impacts of stigmatisation on night-running are numerous. There is limited understanding of the practice; the practice has not been comprehensively investigated, debated and contextualised in contemporary society. The perceived harms of the practice have been publicized, while the potential benefits of night-running have been suppressed. Night-runners continue to be discriminated against in society. 
Night-running is a mysterious activity that many people do not understand. It is stigmatised by society largely because it is conducted under the cover of darkness and with utmost secrecy. Ordinary night-runners perform their acts for amusement and do not intentionally harm other people. Some benefits, such as health and security, may result from night-running. However, there are several unintended harms that result from it. Witches use the guise of harmless night-running to hurt, curse, or even kill their neighbours. Because it is not possible for residents to differentiate between these two categories of nightrunners in the darkness, generalised stigmatisation has developed.

Night-running is a form of indigenous knowledge whose cultural and socioeconomic value should be investigated, debated, validated, and advocated. It is intricately woven into the cultural fabric of residents of Homa Bay County, and will continue being practised in secret with all the associated intentional and unintentional harms. Demystifying the practice, such as by talking about it openly, may clarify the misperceptions surrounding it and lead to its destigmatisation and possible ethical practice. As the world turns to local solutions for local problems, indigenous knowledge such as night-running should not be condemned wholesale without being interrogated. Furthermore, given that indigenous knowledge is dynamic and evolves in response to the emerging needs of society, it is possible that a totally harmless and more-acceptable practice may emerge from night-running as we know it today. This paper is an effort to attract attention to the practice by stimulating debate about its place in modern society.

\section{References}

Agrawal, A. 1995. 'Dismantling the divide between indigenous and scientific knowledge'. Development and Change 26.3, 413-439.

Amuka, P.S.O. 200o. 'The play of deconstruction in the speech of Africa: The role of pakruok and ngero in telling culture in Dholuo'. In I. Karp and D.A. Masolo (eds.), African Philosophy as Inquiry. Bloomington: Indiana University Press, 89-104.

Atieno-Odhiambo, E. 2002. 'Historicising the Deep Past in Western Kenya'. In W.R. Ochieng (ed.), Historical Studies and Social Change in Western Kenya: Essays in Memory of Professor Gideon Were. Nairobi: East African Publishers, 29-41.

Blomberg, J., J. Giacomi, A. Mosher, and P. Swenton-Wall. 1993. 'Ethnographic field methods and their relation to design'. In D. Schuler and A. Namioka (eds.), 
Participatory Design: Principles and Practices. Hillsdale, NJ: Lawrence Erlbaum Associates, 123-155.

Dawo, J.I.A., K.M. Auja, and J.O. Gogo. 2015. 'Analysis of relationship between school workload management and teacher transfer intention in public secondary schools in Mbita and Suba sub-counties, Kenya'. International Journal of Academic Research in Business and Social Sciences 5.12, 13-23.

Fleer, M. 1999. 'Children's alternative views: Alternative to what?' International Journal of Science Education 21.2, 119-135.

Gumbo, F.F. 2008. 'An Adventist missiological response to traditional beliefs in Kenya'. Journal of Adventist Mission Studies 4.1, 105-106.

Harries, J. 2009. 'The name of God in Africa and related contemporary theological development and linguistic concerns'. Exchange 38.3, 271-291.

Herbich, I., and M. Dietler. 2008. Learning, postmarital resocialization of women, and material culture style. In M.T. Stark, B.J. Bowser, and L. Horne (eds.), Cultural Transmission and Material Culture: Breaking Down Boundaries. Tucson: University of Arizona Press, 105-129.

Isaac, M.K. 2014. 'Gender discrimination against women in the punishing of witches among the Abagusii of south-western Kenya'. PhD thesis, University of Nairobi, Kenya.

Johnson, M. 1992. Lore: Capturing Environmental Traditional Knowledge. Ottawa: IDRC. King, A. 1994. 'The time of circumcision'. Anthropology and Humanism 19.2, 138-153.

Langhill, S. 1999. 'Indigenous knowledge: A resource kit for sustainable development researchers in dryland Africa'. Available at: https://idl-bnc-idrc.dspacedirect .org/bitstream/handle/10625/32058/114518.pdf?sequence=1. Accessed 5 July 2017 .

Masolo, D.A. 2010. Self and Community in a Changing World. Bloomington: Indiana University Press.

Nyasani, J.M. 1997. The African Psyche. Nairobi: Theological Printing Press.

Ochieng, W.R. 2002. Historical Studies and Social Change in Western Kenya: Essays in Memory of Professor Gideon S. Were. Nairobi: East African Publishers.

Ocholla, A.B.C. 1976. Traditional Ideology and Ethics among the Southern Luo. Uppsala: Scandinavian Institute of African Studies.

Ocholla, D.N. 2007. 'Marginalised knowledge: An agenda for indigenous knowledge development and integration with other forms of knowledge'. International Review of Information Ethics 7, 1-10.

Oduor, R.M. 2012. 'A critical review of DA Masolo's self and community in a changing world'. Thought and Practice 4.1, 1-24.

Onyancha, O.B., and D.N. Ocholla. 2004. 'An informetric analysis of the corruption literature based on Africa between 1990 and 2001'. South African Journal of Libraries and Information Science 70.2, 86-98. 
Onyango-Abuje, J.C. 1975. Fire and Vengeance. Nairobi: East African Publishing House. Orwa, P. 2013. 'Night runners seek recognition'. Available at: https://www.standardmedia .co.ke/article/2000o896o1/night-runners-seek-recognition. Accessed 16 February 2020.

Picasso, P. 2016. 'Koyaanisqatsi: Life out of balance'. Available at: https://burs arts.wordpress.com/category/sociology/. Accessed 6 July 2017.

Sahai, S. 2003. 'Importance of indigenous knowledge'. Indian Journal of Traditional Knowledge 2.1, 11-14.

Semali, L.M., and J.L. Kincheloe. 2002. What is indigenous knowledge? Voices from the Academy. New York: Routledge.

Smith, L.T. 1999. Decolonizing Methodologies: Research and Indigenous Peoples. New York: Zed Books.

Warren, D.M. 1991.Using Indigenous Knowledge in Agricultural Development, No. 127. Washington DC: World Bank.

Weckenbrock, P., and B. Oldesloe. 2005. 'Livelihoods, vulnerability and the risk of malaria on Rusinga Island/Kenya'. Swiss Tropical Institute. Available at: https://www .freidok.uni-freiburg.de/fedora/objects/freidok:4546/datastreams/FILE1/content. Accessed 1 August 2017 .

Wendo, N. 2016. 'Ethnic stereotyping on Kenyan blog sites in the 2013 political elections: A spurious harbinger of ethnic discord'. In D.O. Orwenjo, O. Oketch, and A.H. Tunde (eds.), Political Discourse in Emergent, Fragile, and Failed Democracies. Hershey, PA: IGi Global, 252-264.

World Bank. 1997. 'Knowledge and skills for the information age, The First Meeting of the Mediterranean Development Forum'; Mediterranean Development Forum. Available at: http://www.worldbank.org/html/fpd/technet/mdf/objectiv.html. Accessed 28 July 2016.

\section{Notes}

1 https://www.bbc.com/news/av/world-africa-48153977/meet-kenya-s-mysterious -night-runners

2 https://nairobinews.nation.co.ke/editors-picks/govt-urges-night-runners-to-suspend -activities-on-census-nights

3 https://www.sde.co.ke/thenairobian/article/2001269322/exposed-there-are-over-1-30o -active-night-runners-in-nairobi

4 https://www.nation.co.ke/counties/Homa-Bay-night-runners-in-trouble/1107872-2748342 ${ }_{-7} \mathrm{f}_{5} \mathrm{pt}$ 4z/index.html 